\title{
Importance of Early Splenectomy in Patients with Hepatosplenic T-Cell Lymphoma and Severe Thrombocytopenia
}

\author{
Andrew A. Gumbs, $\mathbf{M D}^{1}$, Jasmine Zain, $\mathbf{M D}^{2}$, Ellen Neylon, $\mathbf{R N}^{2}$, Barbara MacGregor-Cortelli, $\mathbf{R N}^{2}$, \\ Molly Patterson, $\mathrm{BA}^{2}$, and Owen A. O'Connor, $\mathrm{MD}, \mathrm{PhD}^{2}$ \\ ${ }^{1}$ Department of Surgical Oncology, Fox Chase Cancer Center, Philadelphia, PA; ${ }^{2}$ Herbert Irving Comprehensive Cancer \\ Center, College of Physicians and Surgeons, Columbia University, New York, NY
}

\section{ERRATUM TO: ANN SURG ONCOL DOI 10.1245/S10434-009-0470-0}

In the article by Gumbs et al. entitled "Importance of Early Splenectomy in Patients With Hepatosplenic T-cell Lymphoma and Severe Thrombocytopenia" (Ann Surg Oncol DOI 10.1245/s10434-009-0470-0) the authors Ellen
Neylon, Barbara MacGregor-Cortelli, Molly Patterson were not included in the byline in error.

Accordingly, the correct byline for this article is:

Andrew A. Gumbs, MD, Jasmine Zain, MD, Ellen Neylon, Barbara MacGregor-Cortelli, Molly Patterson, and Owen A. O'Connor, MD, PhD.

The online version of the original article can be found under doi:10.1245/s10434-009-0470-0.

(C) Society of Surgical Oncology 2009

Published Online: 3 July 2009

A. A. Gumbs, MD

e-mail: aagumbs@gmail.com 